\title{
CITY AND SUBURBAN COMPETITION
}

\author{
D. Andrew Austin
}
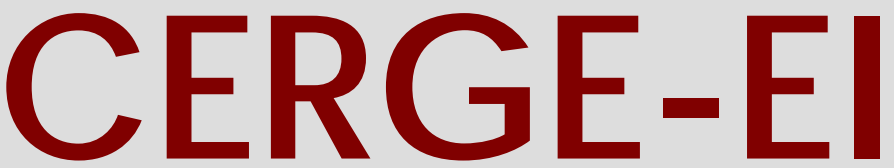

Charles University Centerfor Economic Research and Graduate Education Academy of Sciences of the Czech Republic Economic Institute 


\title{
Working Paper Series 251 (ISSN 1211-3298)
}

\section{City and Suburban Competition}

\author{
D. Andrew Austin
}

CERGE-EI

Prague, February 2005 
ISBN 80-7343-044-4 (Univerzita Karlova v Praze, CERGE)

ISBN 80-7344-033-4 (Národohospodářský ústav AV ČR, Praha) 


\title{
City and Suburban Competition
}

\author{
D. Andrew Austin \\ CERGE-EI \\ PO Box 882 \\ 11121 Prague 1 \\ Czech Republic
}

February 15, 2005

\begin{abstract}
This paper presents an analog to Cournot duopoly in a model of the local public sector, with one city and a suburb. Reaction functions are derived for the mayor of the city and of the suburb, and properties of the Nash equilibria are analyzed. The translation of the Cournot duopoly model is not simply a matter of renaming variables, because of the role of land rents. As residents move, they impose a pecuniary externality on others through higher land prices as well as by changing incentives facing each mayor. Comparative statics results are derived for changes in agricultural land prices and transportation costs and for their effects on city population and rents captured by the city mayor.

Abstract

Tato studie prezentuje analogii Cournotova duopolu na modelu místního veřejného sektoru s jedním městem a předměstím. Model odvozuje reakční funkce pro starostu města a předměstí, a analyzuje Nashovu rovnováhu. $\mathrm{Z}$ důvodu role, kterou hrají ceny pozemků, není aplikace Cournotova duopolu pouze záležitostí přejmenování proměnných; změny bydliště uvalují na obyvatele peněžní externalitu skrze vy̌šsí ceny pozemků. Komparativní statikou jsou odvozeny dopady změn v cenách zemědělských pozemků a nákladů na dopravu na počet obyvatel města a renty zachycené starostou města.
\end{abstract}

JEL Codes: H730, D720, D430

Keywords: Government Competition, Duopoly, Local Public Finance

I wish to thank John Sutton, Libor Dusek and Jose Noguera for useful suggestions. An earlier version of the paper was presented at the 2003 APET conference at Duke University and was the Presidential Lecture for the 2004 Central European Public Economic Theory Conference held at Udine, Italy. I am responsible for remaining errors. 


\section{Introduction}

\subsection{Imperfect Competition and Local Public Finance}

Strategic models have changed how economists think about competition among firms, but have had less influence on how economists think about competition among towns and cities. Three approaches, which are essentially non-strategic, dominate the economic analysis of local public finance. In the Tiebout tradition, in which individuals choose among a set of small jurisdictions offering different tax and public service bundles, towns are treated like firms in a perfectly competitive market. "Leviathan" models are populated with unaccountable politicians, who seek to divert as many public resources as possible to their own end, and residents, who have few or no options of where to live. Politicians in Leviathan models play an analogous role to monopolists in product markets. Land-use models in the Alonzo and von Thuenen tradition provide a third way of analyzing local economies, though these models typically omit any description of political processes. ${ }^{1} \quad$ Just as perfect competition and monopoly fail to describe strategic interactions in product markets, the extremes of Tiebout and Leviathan also fail to capture strategic interactions among cities and suburbs. Cities in a Tiebout model take prices as given, so actions of other cities have no direct effect. In a Leviathan model no rivals exist. As game theory has been integrated into microeconomics, simple models of strategic interactions in private goods markets, such as Cournot and Bertrand competition, have become standard tools. These models provide important insights about strategic interactions among firms, and have become standard tools for strategic analysis and competition policy. This

\footnotetext{
${ }^{1}$ Konishi (1996) is an exception to this, providing a model in which residents affect outcomes both through voting and migration.
} 
paper presents an analog to Cournot duopoly in a model of the local public sector with one city and one suburb. Reaction functions are derived for the mayor of the city and of the suburb, and properties of the Nash equilibria are analyzed. This model also serves as a first step towards a more complex model with multiple suburbs.

Translating the Cournot duopoly model into the context of local public economics is more than a matter of renaming variables due to the role of land rents. As residents move, they impose a pecuniary externality on others through changes in land prices. Land rents also affect the opportunities available to the city mayor who, by charging taxes higher than costs of production, may be able to extract some land rents. When people move they therefore affect others indirectly by changing the incentives facing mayors. Epple and Zelenitz (1981) develop a model of a Leviathan city surrounded by a competitive fringe of suburbs. Individuals consume a private good and housing, which is produced via a convex technology. Perturbations around a Nash equilibrium are used to investigate strategic interactions between a surplus-maximizing city mayor and the suburbs. The city mayor can extract rents, even when residents are free to move to Tiebout-type suburbs, because land is nonreproducible.

This paper looks at a simple model with two jurisdictions, in which city and suburban politicians act strategically. The mutual determination of fiscal decisions of cities and suburbs is the central focus of this analysis. If the city extracts land rents, then a self-interested suburban mayor can also capture some rents, if she is not fully constrained by the political process. The reluctance of residents to leave the city for the suburb, due to agglomeration economies or special amenities of city living, creates land rents in the city that enable the city to charge higher taxes for a given bundle of public services. However, if the city's 
taxes exceed what is needed to fund minimum cost provision, then a suburban mayor may also be able to impose taxes in excess of minimum cost requirements. Thus competition in taxes and services to attract and retain residents creates a link between city and suburban fiscal behavior. Competition will also limit the ability of either mayor to extract from residents land rents stemming from the city's locational advantage. How land rents are split between residents and mayors will depend on transportation costs and the value of suburban land in non-housing uses. Closed-form reaction functions are derived, although no closed form solution exists for Nash equilibria as a function of economic fundamentals.

Including land and the features of a simple spatial model increases the complexity of the model. The model employs a specific functional form which is similar to a quasi-linear utility function that is widely used in the political economy literature (e.g. Persson, Roland and Tabellini 2000). Choosing a suitable functional form leads to a simple reaction function for the city mayor, although the suburban mayor's reaction function is more complicated. Therefore the relationship between Nash equilibria and the economic fundamentals (i.e. the value of land not used for housing and transportation costs) is also more complicated. While some may object to using less than fully general function forms, using specific tractable function forms can provide intuition about complex interactions. Just as simpler models and simulations often preceded more general models in the new economic geography, analysis of competition among governments within a more general setting is the next logical step. In particular, analyzing a model with a specific functional form sheds light on what comparative statics results might go through in a general setting. Of course, the Cournot-Nash and Bertrand-Nash models with linear demands serve as the workhorses of the industrial organization literature. 


\subsection{Competition Among Governments}

Competition among governments has always been a central, if sometimes implicit, theme in public finance. The earliest writers on public finance understood the basics of tax competition, which remains a highly active research area. The Tiebout model has generated a vast literature and more recent papers have integrated median voter models with free mobility among jurisdictions. Tiebout's celebrated insight was that perfect competition among a large set of governments could under certain conditions provide each consumer with a bundle of publicly provided goods and services that matched her preferences and a tax which reflected efficient provision costs.

City officials of one jurisdiction in the midst of many others have limited ability to exploit their residents. A natural interpretation of Tiebout's model is a large collection of suburbs, in which the choices of any one suburb have little effect on the whole. Analyzing how individuals choose towns to live in then parallels the analysis of how people choose what products to buy. Each town offers a bundle of public goods and services along with other amenities, and city officials can benefit when they please residents enough to vote for them, rather than for others, or to live in their cities, instead of elsewhere. City officials, like entrepeneurs, benefit by providing an attractive bundle of goods and services and by charging a price or tax such that a consumer who is willing to pay at least marginal cost will pay just slightly less than the amount that would cause that consumer to choose another supplier. As outside options constrain entrepeneurs to set prices closer to marginal costs (and to the extent that some long-run adjustment process brings marginal costs towards average costs), competition promotes efficiency.

While most models in the Tiebout tradition examine the situation in which 
jurisdictions face a perfectly competitive environment (e.g. Konishi 1996), other papers incorporate some features of imperfect competition. Epple and Zelenitz (1981) find that individual mobility of residents within a set of competing jurisdictions cannot prevent a bureaucratic monopolist from capturing rents. Because land cannot be manufactured and jurisdictional boundaries are fixed, fragmentation of local government into a larger number of competing jurisdictions cannot create sufficient competitive pressure to generate first-best results. Residents then need other ways to constrain politicians, such as electoral accountability.

A second generation of fiscal federalism research looks at how jurisdictions compete with each other when factors of production are mobile. Wildasin (1988) considers a collection of jurisdictions engaged in fiscal competition, each with a single individual, and all competing for mobile capital. He finds that the Nash equilibria for a game in which jurisdictions compete by setting tax rates differ from the Nash equilibria for a game in which jurisdictions compete in public expenditure levels. ${ }^{2}$ Wildasin (2003) presents a dynamic tax competition game in which factors of production are mobile, but are subject to adjustment costs. This gives governments an incentive to tax relatively immobile factors more heavily, despite the long-term costs of such a policy.

Policy-oriented researchers have also become increasingly interested in competition among governments. Breton's Competitive Governments (1996) analyzes "internal competition" and "external competition" among different types of governments. Brandl (1998) argues that introducing more competitive mechanisms into U.S. state government operations would acheive higher levels of efficiency and would make governments more responsive to the public.

In the present paper residents live in either a city or a suburb. Both have

\footnotetext{
${ }^{2}$ This appears similar to the results of Vives (1985) and Vives and Singh (1986) for Bertrand and Cournot competition with differentiated products.
} 
unelected mayors who may attempt to extract rents. While residents cannot choose who runs the government, they can vote with their feet to another jurisdiction. If more voters move from the city to the suburb, the suburb expands into the surrounding agricultural area. Thus unlike Epple and Zelenitz (1981) the supply of suburban housing is perfectly elastic. While the ability of developers to convert "raw land" into new suburban housing tethers the suburban housing price to the value of agricultural land, the suburban mayor may be able to extract more rents if suburban locations are in high demand. City and suburb are then intertwined by migration decisions, so that the population and efficiency of government are determined through a nontrivial strategic interaction between the city and suburban mayors.

\section{The Model}

The model comprises a closed metropolitan area populated by a continuum $[0,1]$ of people who either live in a city $C$ and in a suburb $S$. The city has $N_{C}$ residents and a mayor. The suburb has $N_{s}=1-N_{C}$ residents and its own mayor. All residents must work in a central business district, and getting there costs city residents zero and suburban residents $t$. More generally, $t$ represents locational advantages of the city that do not depend on population, so $t$ could represent agglomeration effects or special urban amenities unavailable in the suburbs.

The city's boundaries are fixed and contain one unit of land, but the suburb's boundaries are not fixed. Agricultural land, which yields rent $p_{A}$ per unit, can be converted to residential use in the suburb at zero cost. The suburban government cannot restrict the supply of land for residential use. The cost of structures is ignored, so ground rent is the sole cost of housing. 
Each resident earns a fixed income $\omega$ and consumes a private consumption good $c$, which serves as the numeraire, and housing $s$. Housing costs $p_{C}$ in the city and because the supply of suburban land is perfectly elastic its price is $p_{A}$. One half of the metropolitan area is endowed with an equal share of the single unit of city land, and the other half of residents own no land. Let $l_{C}(i)$ represent the endowment of land for person $i$, defined as

$$
l_{C}(i)=\left\{\begin{array}{l}
2 \text { if } i \in\left[0, \frac{1}{2}\right] \\
0 \text { if } i \in\left(\frac{1}{2}, 1\right]
\end{array}\right.
$$

where the city land adding-up constraint is $\int_{0}^{1 / 2} l_{C}(i) \cdot d i=1$.

Agricultural land, which could be used for housing in the suburb, is owned by farmers living outside of the metropolitan area. The model is therefore not technically closed, but this does not matter because these farmers earn no rents. A modified model with some residents endowed with agricultural land would be fully closed, but this would only add notational complication. Residents act nonstrategically and the mayors anticipate the behavioral responses of residents.

Imperfect competition in the political arena allows politicians to capture land rents. These can be used to maintain political power, such as through patronage schemes, or to increase redistributive expenditures. Of course, redistributive expenditures can have both political and altruistic aims. For example, the mayor might run a traditional patronage regime in which jobs, in which low productivity is tolerated, are exchanged for political support; or perhaps the mayor has a stronger taste for redistribution than does a typical resident. ${ }^{3}$ The city mayor can charge city residents $\gamma_{C}$ and the suburban mayor can charge

\footnotetext{
${ }^{3}$ Few mayors who headed patronage machines earned large personal fortunes, and a few such as James Curley of Boston died broke, suggesting either a nearly unlimited interest in redistribution and sharing of gains, or a limited ability to manage money.
} 
residents $\gamma_{S}$. The quantities $\gamma_{C}$ and $\gamma_{S}$ may represent additions to a mayor's personal or political "slush fund" or redistributive expenditures which indirectly benefit the mayor but do not enter the utility function of residents. The city mayor maximizes $N_{C} \cdot \gamma_{C}$ and the suburban mayor maximizes $N_{S} \cdot \gamma_{S}$.

The city provides a local public good $g_{C}$ financed by tax $\tau_{C}$, and the suburb provides $g_{S}$ and charges proportional tax $\tau_{S}$. Each government uses a linear production technology. In the suburb one unit of tax revenues produces $f$ units of per capita public good provision, so $g_{S}=f \cdot \tau_{S}$. The city gets a productivity shock $\varepsilon$ so $g_{C}=f \cdot(1+\varepsilon) \tau_{C}$. The productivity term $\varepsilon$ may be negative, reflecting a cost disadvantage for the city which offsets some of its locational advantage.

\subsection{Metropolitan Residents' Behavior}

All residents have a utility function $u(c, s)=c+\sqrt{s}+k \ln g$. City residents face a budget constraint

$$
\omega+\left[l_{C}(i)-s\right] p_{C}-c-\gamma_{C}-\tau_{C} \geqq 0,
$$

and suburban residents face a budget constraint

$$
\omega+l_{C}(i) \cdot p_{C}-s p_{S}-c-t_{S}-\gamma_{S}-\tau_{S} \geqq 0 .
$$

Residents take prices and the actions of mayors as given. However residents choose the tax rate in their jurisdiction by a majority-rule vote using an openagenda process. A suburban resident's maximization problem (UtilMax-S) and a city resident's problem (UtilMax-C) are then

$\max u(c, s)=c+\sqrt{s}+k \ln g$ such that 
(i) $\omega+p_{C} \cdot l_{C}(i)+p_{A} \cdot s-c-t-\gamma_{S}-\tau_{S} \geqq 0$

$($ UtilMax-S $)$

(ii) $c \geqq 0$;

(iii) $s \geqq 0$

$\max u(c, s)=c+\sqrt{s}+k \ln g$ such that

(i) $\omega+p_{C} \cdot l_{C}(i)-p_{C} \cdot s-c-\gamma_{C}-\tau_{C} \geqq 0 \quad(\lambda)$

$($ UtilMax-C)

(ii) $c \geqq 0$;

(iii) $s \geqq 0$.

The first-order conditions for an interior solution are:

$$
\begin{aligned}
1-\lambda+\eta & =0 \\
\frac{\sqrt{s}}{2 s}-\lambda \cdot p_{j} & =0 ; \quad j=\{A, C\} \\
\frac{k}{\tau_{j}^{*}}-\lambda & =0 ; \quad j=\{S, C\} .
\end{aligned}
$$

If the endowment $\omega$ is sufficiently high, so that $\eta=0$, demand functions are then:

$$
\begin{array}{rlrl}
s\left(p_{C}\right) & =\frac{1}{4 p_{C}^{2}} & \text { individual housing demand in the city } \\
s\left(p_{S}\right) & =\frac{1}{4 p_{A}^{2}} & \text { individual housing demand in the suburb } \\
c\left(\omega, p_{C} ; \gamma_{C}\right) & =\omega+p_{C} \cdot l_{C}(i)-\frac{1}{4 p_{C}}-\gamma_{C}-\tau_{C} \quad \text { private consumption in the city } \\
c\left(\omega, p_{A}, t ; \gamma_{S}\right) & =\omega+p_{C} \cdot l_{C}(i)-\frac{1}{4 p_{A}}-t-\gamma_{S}-\tau_{S} & \text { private consumption in the suburb. }
\end{array}
$$

Voters choose $\tau_{j}^{*}=k, j=\{S, C\}$ unanimously in each jurisdiction. In the city the land market clears when $N_{C}=4 p_{C}^{2}$. Because the city population cannot exceed one the price of city housing must be less than one half for the city land market to clear. Thus we restrict attention to situations where $1 / 2 \geq p_{C}{ }^{4}$

\footnotetext{
${ }^{4}$ The price of housing in the city is not an economic fundamental. How this upper bound on
} 
The equilibrium rental rate for city housing is $p_{C}^{*}=\frac{\sqrt{N_{C}}}{2}$, so that prices for city housing rise with city population. Similarly, total suburban demand for housing is $\frac{1-N_{C}}{4 p_{A}^{2}}$, while the supply of housing is perfectly elastic at price $p_{A}$.

Because individuals are mobile, in equilibrium residents receive equal utility in each jurisdiction. ${ }^{5}$ Indirect utility for a city resident at the equilibrium housing price is

$$
\left.v\left(p_{C}, \gamma_{C} ; \omega\right)\right|_{p_{C}=\frac{\sqrt{N_{C}}}{2}, \tau_{j}^{*}=k}=\omega+\frac{l_{C}(i) \cdot \sqrt{N_{C}}}{2}-k+\frac{1}{2 \sqrt{N_{C}}}-\gamma_{C}+k \ln [f \cdot(1+\varepsilon) k]
$$

A suburban resident's indirect utility at the equilibrium housing price is

$\left.v\left(p_{A}, \gamma_{S}, t ; \omega\right)\right|_{p_{C}=\frac{\sqrt{N_{C}}}{2}, \tau_{j}^{*}=k}=\omega+\frac{l_{C}(i) \cdot \sqrt{N_{C}}}{2}-k+\frac{1}{4 p_{A}}-t-\gamma_{S}+k \ln (f \cdot k)$.

The equal utility condition, equating the indirect utility functions of a city and a suburban resident, for owners and non-owners alike is then:

$$
\frac{1}{2 \sqrt{N_{C}}}+k \ln (1+\varepsilon)=\frac{1}{4 p_{A}}+\left(\gamma_{C}-\gamma_{S}\right)-t .
$$

Solving for $N_{C}$ gives the city's population economic fundamentals and the rate of slack charged by each mayor. This resembles the population supply function derived by Fujita (1989, pp.140-50).

$$
N_{C}\left(\gamma_{C}, \gamma_{S} ; t, \varepsilon\right)=\min \left[1,\left(\frac{2 p_{A}}{1+4 p_{A}\left[\gamma_{C}-\gamma_{S}-t-k \ln (1+\varepsilon)\right]}\right)^{2}\right] .
$$

the city housing price relates to economic fundamentals will be discussed below in the section on capitalization. That section shows there is an increasing monotonic relationship between the agricultural rental rate and the city housing price for a given level of transportation costs.

${ }^{5}$ This presumes that all residents have interior solutions to maximization programs in both locations. If sorting among residents with different levels of endowment occurs, some may have strictly greater indirect utility in one location than in another. This possibility is considered in more detail in the next section. 
This function describes population as a function of three sets of variables: the difference in slack $\left\{\gamma_{C}-\gamma_{S}\right\}$ which is determined by strategic interaction between the city and suburban mayors; the price of agricultural land $p_{A}$; and the economic advantages of the city reflected in the city's productivity shock $\varepsilon$ and transportation cost $t$.

All citizens live in the city if $\gamma_{S}-\gamma_{C}+t+k \cdot \ln (1+\varepsilon) \geq \frac{1}{4 p_{A}}-\frac{1}{2}$. Thus the suburb exists only if the opposite inequality holds, which occurs when suburban housing is sufficiently cheap to offset the city's natural economic advantages and the difference in levels of slack.

\subsubsection{Corner Solutions}

If the endowments are not large enough to allow residents positive levels of consumption, then residents are forced to reduce either public or housing expenditures. ${ }^{6}$ If the Lagrange multiplier $\eta>0$ then private consumption is zero. Such residents will be called consumption constrained and must reduce their housing expenditures. The following analysis focuses on transport costs because as the city population approaches zero, agricultural land prices approach zero, which is an economically uninteresting case. The suburban population approaches zero as transportation or productivity differences make locations outside the city increasingly unattractive relative to city locations. If the decisive surbuban voter is consumption constrained the level of public provision will also be reduced.

\footnotetext{
${ }^{6}$ In a richer model that includes different endowments for different people, analysis of corner solutions becomes important because some voters would have zero consumption if they changed towns. If only some voters have interior solutions to maximization programs in both towns then the elasticity of the population supply with respect to slack decreases ceteris paribus relative to a situation where all voters have interior solutions.
} 
Housing expenditure is

$$
s=\frac{\omega+p_{C} \cdot l_{C}(i)-t-\tau_{S}-\gamma_{S}}{p_{A}} \leq \frac{1}{4 p_{A}^{2}}
$$

Consider a comparative statics exercise where transportation costs increase. As these costs rise non-owners become consumption constrained at some point, while initially property owners will not be consumption constrained. Non-owners then leave the suburb in greater numbers, so the decisive voter will be a property owner, who will set the tax rate $\tau_{S}^{*}=k$. However, once owners become consumption constrained the tax rate falls to $\tau_{S}^{*}=2 k p_{A} \sqrt{s}$, so

$$
s=-k+\sqrt{\left(k^{2}+\frac{\omega+p_{C} \cdot l_{C}(i)-t-\gamma_{S}}{p_{A}}\right)} \text { and } \tau_{S}^{*}=k \cdot 2 p_{A} .
$$

This alters the equal utility conditions, and thus the elasticity of population with respect to slack. Indirect utility for consumption-constrained suburban residents will be

$$
\left.v^{\operatorname{CORNER}}\left(p_{A}, \gamma_{S}, t ; \omega\right)\right|_{p_{C}=\frac{{\sqrt{N_{C}}}_{2}, \tau_{j}^{*}=k}{p_{A}}}=\sqrt{l_{C}(i)+\frac{\omega-t-\tau_{S}-\gamma_{S}}{p_{A}}}+k \ln \left(f \cdot \tau_{S}^{*}\right)
$$

Suppose owners are not consumption constrained in either the city or the suburb. Then if non-owners would be consumption constrained if they lived in the suburb, they would then strictly prefer to live in the city. This result is Proposition 1, which relies on a single-crossing property of preferences. Because the voter on the margin between living in the city and in the suburb is an owner, and because owners have the same equal utility condition as in the above section, the population supply function is not affected by non-owners facing a corner solution. 
Proposition 1 If owners are not consumption constrained in both the city and suburb, and if non-owners would be consumption constrained if they resided in the suburb but not in the city, then all non-owners choose to live in the city.

Proof: See Appendix.

When owners are consumption constrained, they will be the only suburban residents. After including the city housing market clearing condition their equal utility condition becomes

$$
\begin{aligned}
\omega+\sqrt{N_{C}}-k-\gamma_{C}+\frac{1}{2 \sqrt{N_{C}}}+k \ln (1+\varepsilon) \\
=\sqrt{\frac{\omega+\sqrt{N_{C}}-t-\gamma_{S}}{p_{A}}}+k \ln \left(2 p_{A} \cdot \sqrt{-k+\cdot \sqrt{k^{2}+\frac{\omega+\sqrt{N_{C}}-t-\gamma_{S}}{p_{A}}}}\right)
\end{aligned}
$$

Unfortunately there is no closed-form solution for the city population in terms of fundamental parameters. This intractability is due to the dependence of the city population on parameters, such as $\omega$, which drop out for interior solutions. That is, the separable, quasi-linear utility function simplifies the analysis enormously for interior solutions, but for a corner solution the parameters are tied together in complex ways. In particular the endowment of city land affects demand through income effects, which disappear when residents have interior solutions. Nonetheless it is clear that as the consumption constraint binds owners in the suburb, so that marginal utility rises as housing and public good consumption falls, this allows the city mayor to increase the rate of slack. That is, when the suburban mayor increases the rate of slack when its residents face corner solutions, the opportunity costs to residents become larger than in the case when residents can find interior solutions, which allows the city mayor to demand a higher rate of slack. 
Cases in which some residents are consumption constrained were they to live in the suburb could be analyzed either using calibration and numerical techniques or by adopting a model with outside ownership of all land. However, these approaches are beyond the scope of this paper and are left for future research. The remainder of this paper focuses on situations in which no resident is consumption constrained.

\subsection{City and Suburban Mayors' Behavior}

Having specified the behavior of residents, summarized by the population supply function, the mayors' choices can be analyzed. Each mayor decides what level of surplus to extract from each resident. Raising $\gamma_{C}$ increases the resources taken from each city resident, but decreases the city population. However, a higher $t$ or higher agricultural rents increases the city's population ceteris paribus. The suburban mayor faces a similar decision with the appropriate changes of signs. However, because of the locational advantage of the city these decisions are not symmetric.

The population supply function acts like a demand for city residence function and $\gamma_{C}$ acts like a price variable controlled by the mayor. The revenue captured by the city mayor as a function of $\gamma_{C}$ looks like a total revenue curve for a standard monopoly pricing problem. The city mayor then maximizes the resources at her disposal by finding the top of the "total slack" function. Figure 1 presents a family of "total slack" functions. 


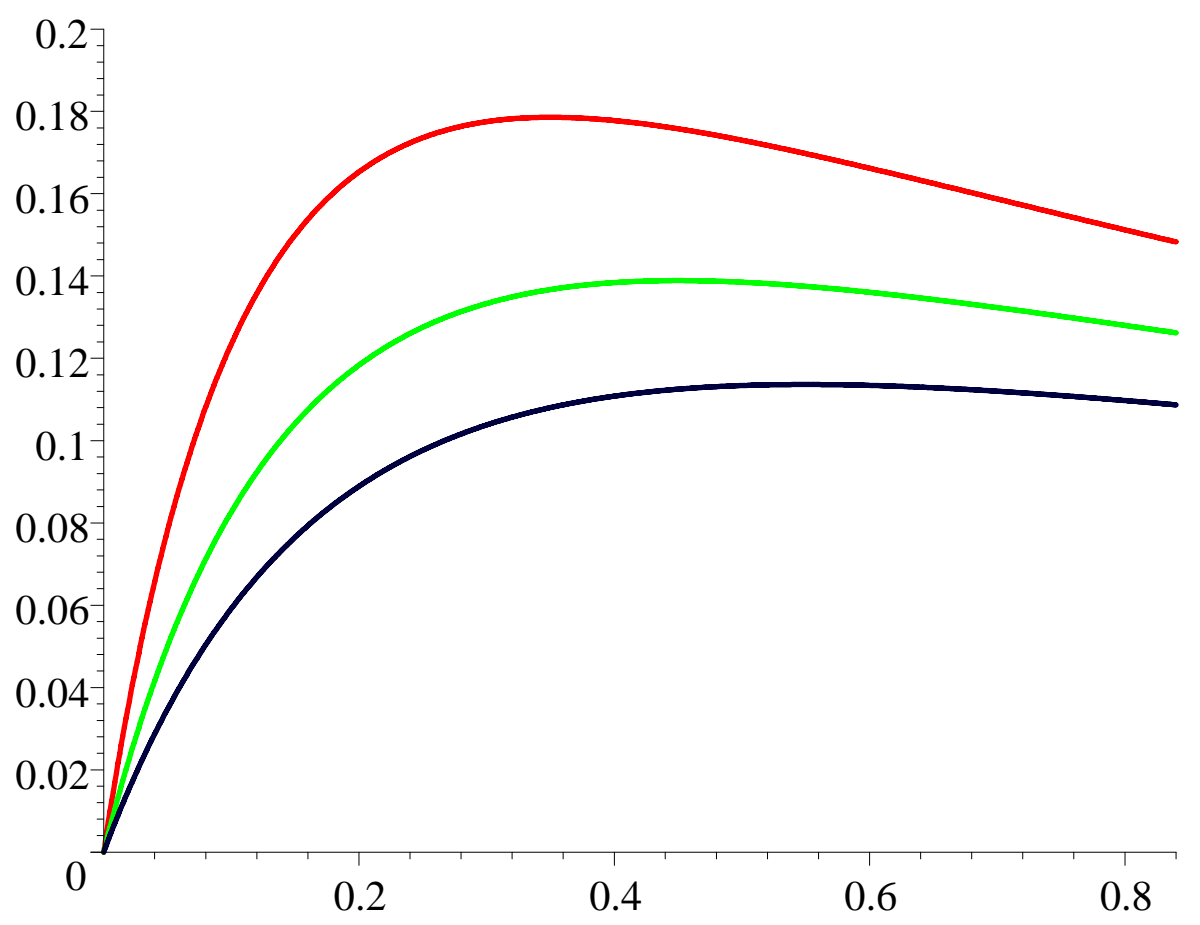

Figure 1: A Family of Total Slack Functions for the City Mayor

Legend: From the lowest to the highest lines; $t=0.5 ; t=0.6 ; t=0.7$. For all lines shown here $p_{A}=0.2 ; \gamma_{S}=0.2 ; \varepsilon=0$.

The city mayor solves the program

$$
\max _{\gamma_{C} \geq 0} \gamma_{C} \cdot N_{C}\left(\gamma_{S}, \gamma_{C} ; t, \varepsilon\right) . \quad(\text { Slack-C })
$$

The first-order condition can be rearranged to yield a familiar monopolist's condition:

$$
\frac{\partial N_{C}\left(\gamma_{S}, \gamma_{C} ; t, \varepsilon\right)}{\partial \gamma_{C}} \frac{\gamma_{C}}{N_{C}\left(\gamma_{S}, \gamma_{C} ; t, \varepsilon\right)}=-1
$$

Inserting the population supply function, in the case that all residents face interior 
solutions in both city and suburb, gives the city mayor's reaction function:

$$
\gamma_{C}\left(\gamma_{S} ; p_{A}, t, \varepsilon\right)=\max \left(\frac{1}{4 p_{A}}-\gamma_{S}-t-k \ln (1+\varepsilon), 0\right)
$$

Figure 2 shows the city mayor's reaction function for three sets of parameter values. The form of the city mayor's reaction function implies two important results. So long as $\gamma_{C}\left(\gamma_{S} ; \cdot\right)>0$, the city and suburban rates of slack and the transport costs sum to a constant, which is restated as Proposition 2.

Proposition 2 If no one is consumption constrained in the city or in the suburb, a decrease in transportation costs will be completely offset by the combined increases in city and suburban slack.

Proof: Obvious, given that for any Nash equilibria the city mayor uses his best response function.

Proposition 2 highlights differences between the Cournot-Nash equilibrium for firms in a product market and the equilibrium in the city-suburb game. In the city-suburb game reductions in transport costs are not passed on to residents. However, having suburban competition does prevent the city mayor from expropriating all available wealth from residents. Without this competitive constraint private and public consumption would be zero. Proposition 2 does not state whether it is city or suburban slack which rises to offset decreases in transport costs. How each mayor's rate of slack varies in equilibrium depends on the elasticity of city or suburban population with respect to city and suburban slack.

Even before analyzing the suburban mayor's behavior, a lower bound on the city rate of slack can be determined, which is described in Proposition 3.

Proposition 3 If all residents face interior solutions in the city and surburb 
and if the city mayor is a total slack maximizer, then the city rate of slack is at least one-fourth.

Proof: Suppose $\gamma_{C}>0$. Substituting the reaction function into the population supply function gives result $N_{C}=\frac{2 p_{A}}{8 p_{A} \gamma_{C}}=\frac{1}{4 \gamma_{C}}$. If $\gamma_{C}=0$ then $\frac{1}{4 p_{A}}-\gamma_{S}-t-k \ln (1+\varepsilon) \geq 0$ which implies the denominator of the population supply function is either zero and the city population is undefined, or negative which describes an economically irrelevant case in which increasing city slack leads to a higher city population. Thus $\gamma_{C}=0$ cannot be a maximizing value.

Higher transportation costs or a positive productivity shock $(\varepsilon)$ shift the city mayor's reaction function downwards, and higher agricultural rents shift the reaction function upwards. Figure 2 shows the city mayor's reaction function for selected parameter values.

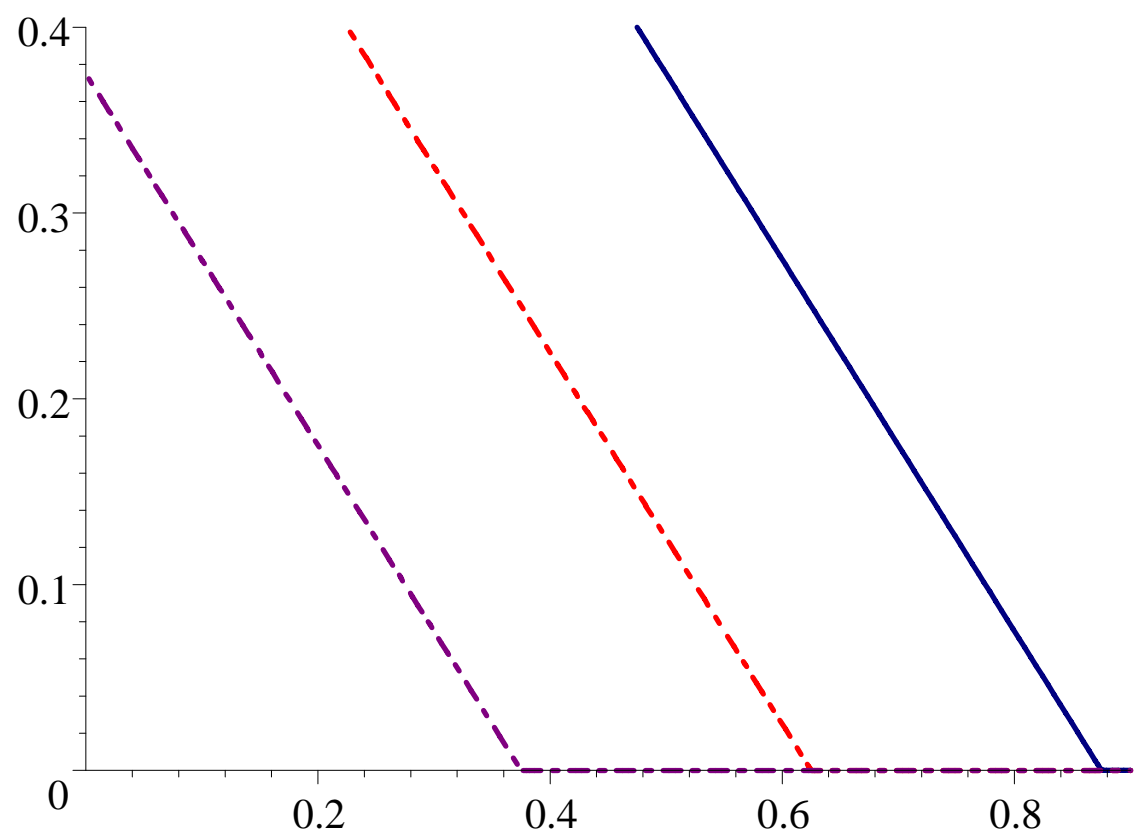

Figure 2: City Mayor's Reaction Function 
Legend: $p_{A}=1 / 2$ for dashed line; $p_{A}=1 / 3$ for dot-dashed line; and $p_{A}=1 / 4$ for the solid line; $t=1 / 8$ for all lines.

The suburban mayor's problem is similar, but not symmetric due to the suburb's elastic border and transportation costs:

$$
\max _{\gamma_{S} \geq 0}\left[1-N_{C}\left(\gamma_{C}, \gamma_{S} ; t, \varepsilon\right)\right] \cdot \gamma_{S}
$$

The solution is again the familiar monopoly pricing rule:

$$
\frac{\partial N_{S}\left(\gamma_{C}, \gamma_{S} ; t, \varepsilon\right)}{\partial \gamma_{S}} \cdot \frac{\gamma_{S}}{N_{S}\left(\gamma_{C}, \gamma_{S} ; t, \varepsilon\right)}=-1
$$

Substituting the population supply function into this first-order condition and solving for $\gamma_{S}$ yields the suburban mayor's reaction function:

$$
\gamma_{S}\left(\gamma_{C} ; p_{A}, z\right)=\max \left(\frac{Q\left(\gamma_{C}, p_{A}, t, z\right)}{12 p_{A}}-\frac{p_{A}}{Q\left(\gamma_{C}, p_{A}, z\right)}+\frac{1}{4 p_{A}}+\left(\gamma_{C}-z\right), 0\right)
$$

where $Q\left(\gamma_{C}, p_{A}, z\right) \equiv$

$$
\sqrt[3]{\left(12 \sqrt{\left(12 p_{A}^{6}+81 p_{A}^{4}+648 p_{A}^{5}\left(\gamma_{C}-z\right)+1296 p_{A}^{6}\left(\gamma_{C}-z\right)^{2}\right)}-108 p_{A}^{2}-432 p_{A}^{3}\left(\gamma_{C}-z\right)\right)}
$$

and where $z \equiv t+k \cdot \ln (1+\varepsilon)$, the city's economic advantage over the suburb from its locational advantage and higher productivity. Only the difference between the city's rate of slack and $z$ matters for this reaction function.

The suburban mayor's reaction function is shown in Figure 3 for three different levels of agricultural rent. As agricultural rent falls, the suburban reaction function shifts upwards. As before, the suburban mayor's reaction function is restricted to positive values. The suburban population cannot reach one for finite parameters and the maximization is irrelevant if the suburban population is zero, so boundary solutions are impossible. The reaction function $\gamma_{S}\left(\gamma_{C} ; p_{A}, z\right)$ has a 
slope that is positive and less than one. When the city's rate of slack increases, the suburban mayor also raises the rate of slack, but by a lesser proportion. ${ }^{7}$

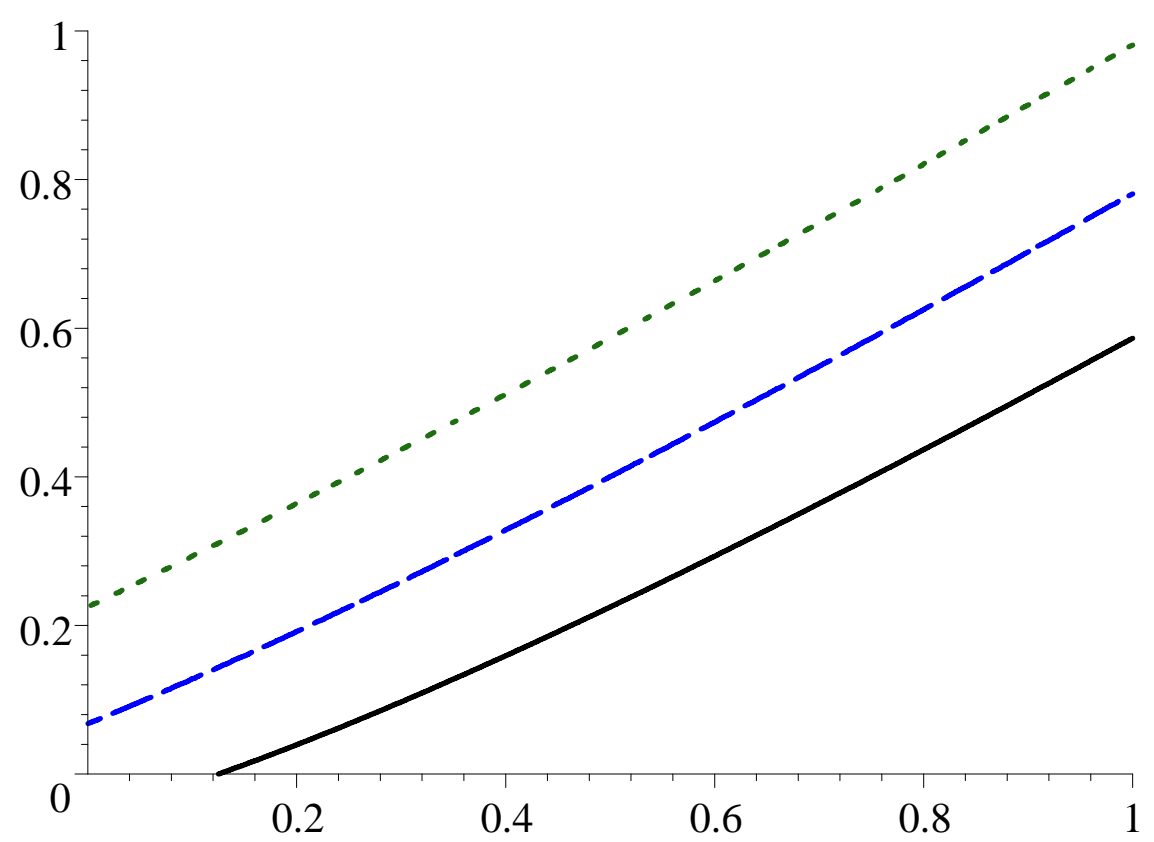

Figure 3: Suburban Mayor's Reaction Function

Legend: $p_{A}=1 / 2$ for solid line; $p_{A}=1 / 3$ for dot-dashed line; and $p_{A}=1 / 4$ for the dotted line; $t=1 / 8$ for all lines. Vertical axis represents the suburb's rate of slack.

\section{Nash Equilibrium}

A Nash equilibrium is a strategy pair $\left\{\gamma_{C}^{*}, \gamma_{S}^{*}\right\}$ such that both mayors choose best responses. Unlike the Cournot duopoly model with linear demand, closed form functions describing how Nash equilibrium quantities depend on fundamental data of the economy cannot be derived. However, comparative statics for

\footnotetext{
${ }^{7}$ This is true for all of a wide range of parameter values which were tried. However, the complexity of this reaction function makes finding an analytic result impossible. Note that if the term $\frac{Q\left(\gamma_{C}, p_{A}, t, z\right)}{12 p_{A}}-\frac{p_{A}}{Q\left(\gamma_{C}, p_{A}, z\right)}$ were zero suburban slack would then rise one-for-one with city slack.
} 
Nash equilibria can be shown using numerically-computed graphs for various values of agricultural rent and the city's economic advantage $z$. Because a change in $z$ has the same effect as a change in transport costs $t$, for simplicity the analysis below focuses on changes in $t$.

\subsection{Determination of Equilibria}

In Nash equilibrium the rates of slack chosen by the mayors are a function of agricultural rents and transport costs. Figure 4 shows Nash equilibria for three different levels of agricultural land rent, while the difference in transport costs is held at one eighth. In Figure 4, reaction functions are shown for agricultural rent levels of $1 / 3,1 / 4$ and $1 / 5$. The city mayor's reaction function is affine while the suburban mayor's reaction function is roughly parabolic. As agricultural rents rise Nash equilibria move to the "southeast." As this occurs the city rate of slack falls less than the suburban rate of slack. Thus higher agricultural rents make the suburb a relatively less attractive place to live, which rapidly reduces the suburban mayor's ability to collect slack.

Next, transportation costs are varied while agricultural rent is held fixed. In Figure 5, reaction functions are shown for transport costs of 1/8, 1/4, 3/8, 1/2 and 5/8. Higher transportation costs shift the city mayor's reaction function to the right, and shift the suburban mayor's reaction function down. Thus in Nash equilibrium, city slack increases and suburban rent decreases as transportation costs rise, so the locus of equilibria moves "southwest" as $t$ increases. Thus increasing agricultural rents and transportation costs have roughly opposite comparative statics effects. Proposition 2 implies that a decrease in transportation costs will be offset by the combined increased rates of slack for the city and suburb. This result can be seen from Figure 5. As transportation costs fall 
from $t=5 / 8$ to $t=1 / 8$, city slack increases from 0.2862 to 0.3796 , an increase of 0.093, while suburban slack increases from 0.0888 to 0.4954 , an increase of 0.4066 .

Suburban slack absorbs over $80 \%$ of the increase in transport costs in this case.

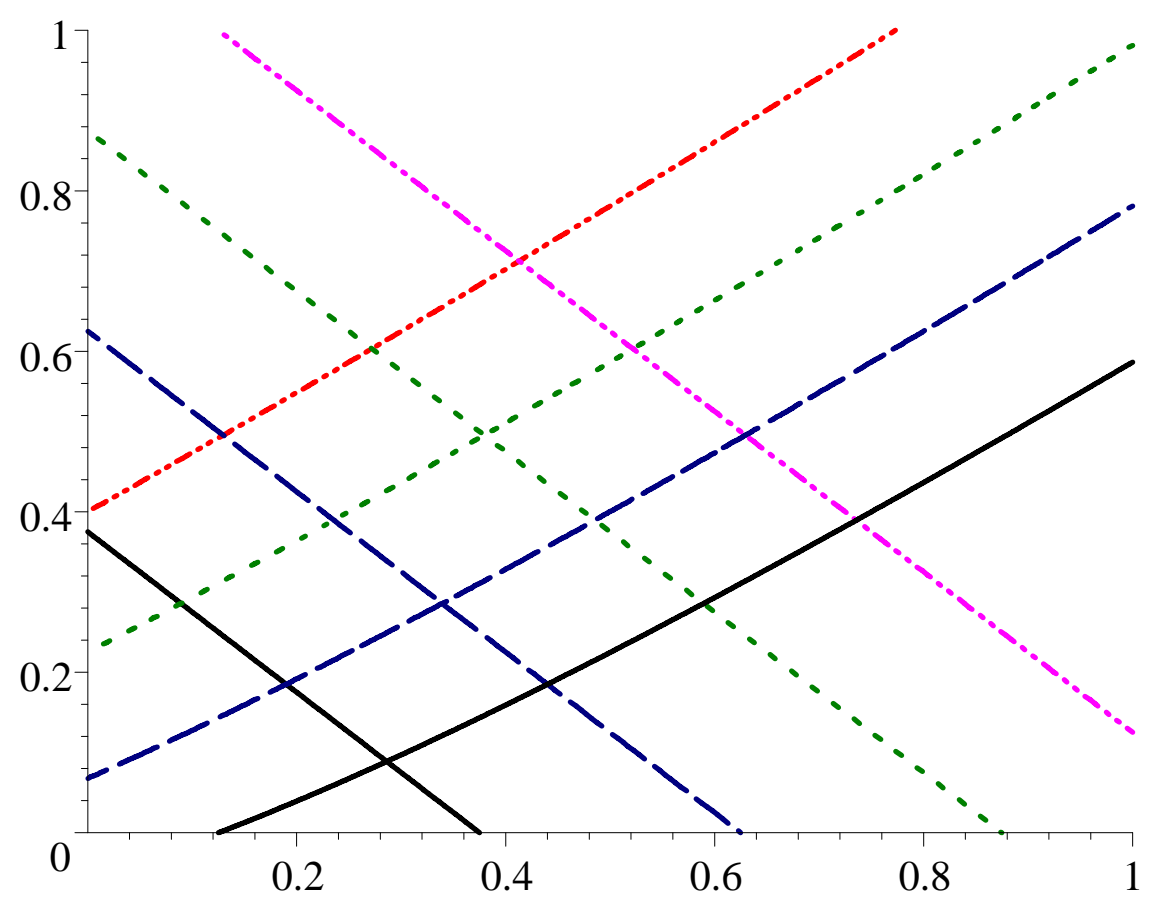

Figure 4: Nash Equilibria for Various Levels of Agricultural Rent

Legend: From bottom to top: $p_{A}=1 / 2$ for solid lines; $p_{A}=1 / 3$ for dashed lines; $p_{A}=1 / 4$ for dotted lines; $p_{A}=1 / 5$ for dot-dashed lines; $t=1 / 8$ for all lines. Vertical axis represents the suburb's rate of slack. 


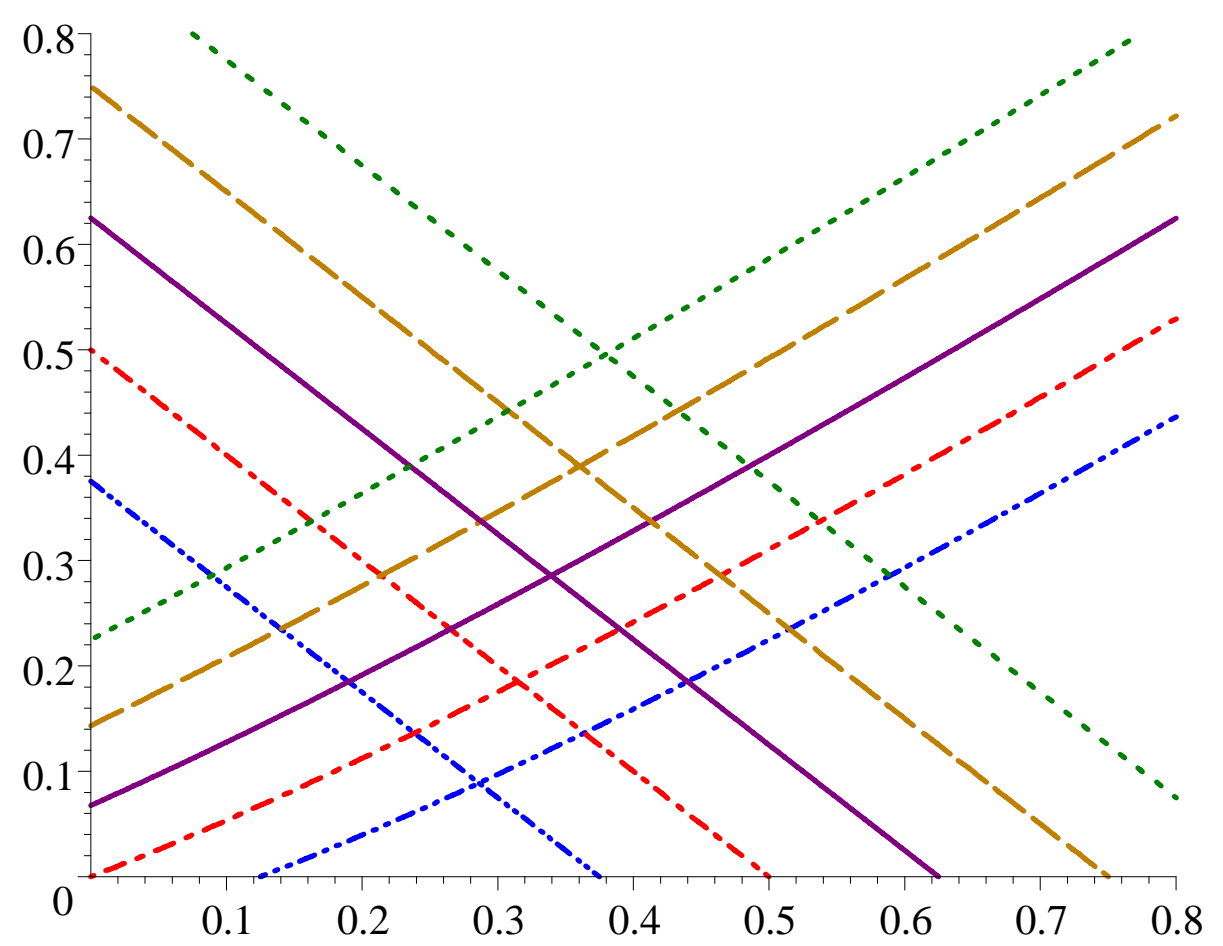

Figure 5: Nash Equilibria for Various Transportation Costs

Legend: From top to bottom: $t=1 / 8$ for dotted lines; $t=1 / 4$ for dashed lines; $t=3 / 8$ for solid lines; $t=1 / 2$ for dot-dashed lines; $p_{A}=1 / 4$ for all cases. Vertical axis represents rates of slack, horizontal axis shows transport costs.

\subsubsection{Rates of Slack in Equilibrium}

Equilibrium rates of slack are functions of the underlying parameters, transport costs and the value of agricultural land. The relationship between agricultural rent and city and suburban rates of slack is shown in Figure 6 . The suburban rate of slack schedules are steeper at low values and cross the city schedules from above. Higher agricultural land values reduce both rates of slack. Higher transportation costs shift the schedule of city slack upwards, but shifts the schedule of suburban slack downwards. As agricultural land values approach 
zero, the city population also approaches zero, so the city mayor collects higher rates of slack from a smaller and smaller population.

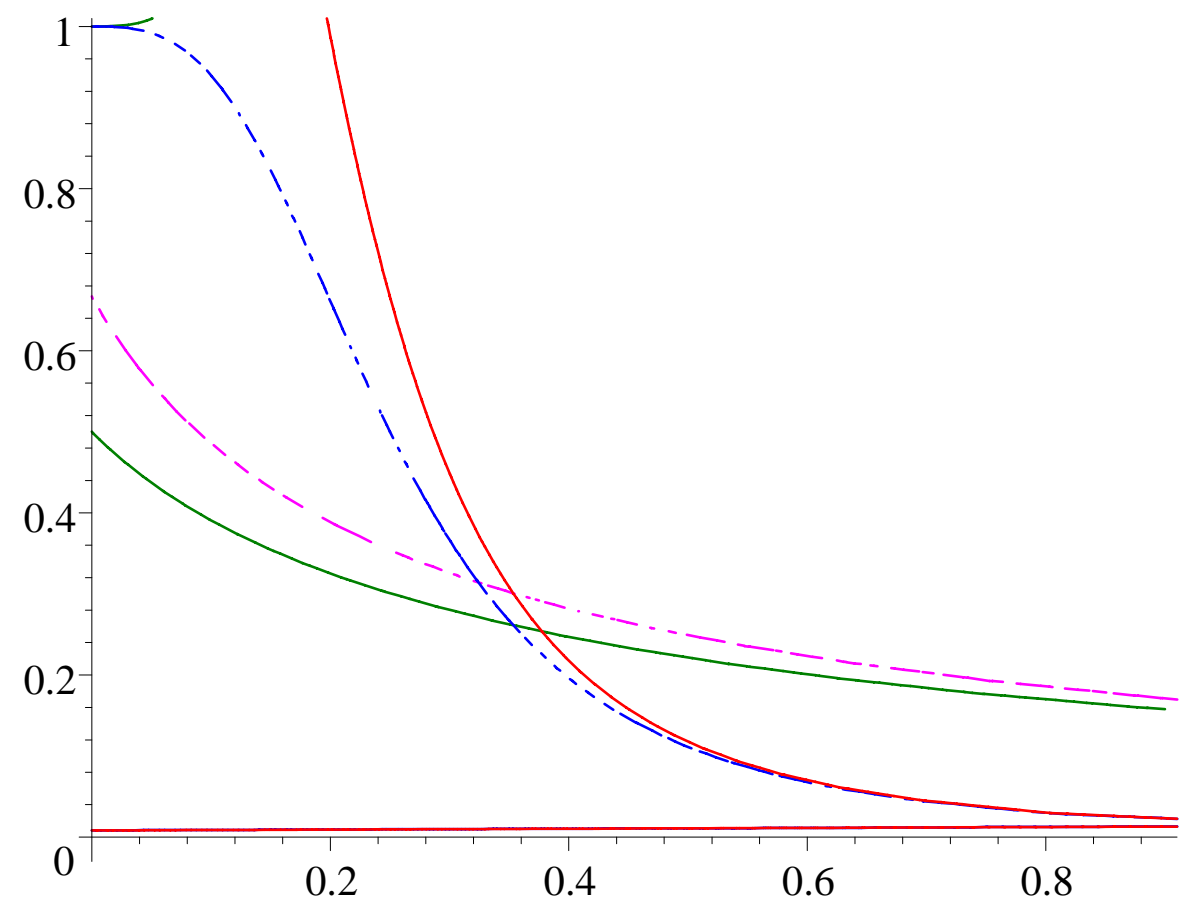

Figure 6: Equilibrium City and Suburban Rates of Slack as a Function of Agr.

Rent

Legend: Solid lines show city and suburban rates of slack in Nash equilibrium when $t=1 / 8$; dashed lines show city and suburban rates of slack when $t=1 / 4$. Vertical scale shows rates of slack, horizontal scale shows $p_{A}$. City slack schedules appear as convex functions; suburban slack schedules converge more quickly to zero as $p_{A}$ increases.

Figure 7 shows the equilibrium city and suburban rates of slack as a function of transport costs. Increasing agricultural land value shifts the loci of equilibrium rates of slack inwards and makes the locus of city rates of slack steeper. Proposition 2 implies that the city rate of slack varies inversely with transportation costs. Figure 7 shows the city's rate of slack decreases at a decreasing rate as 
transportation costs rise, which is when the suburban population shrinks towards zero.

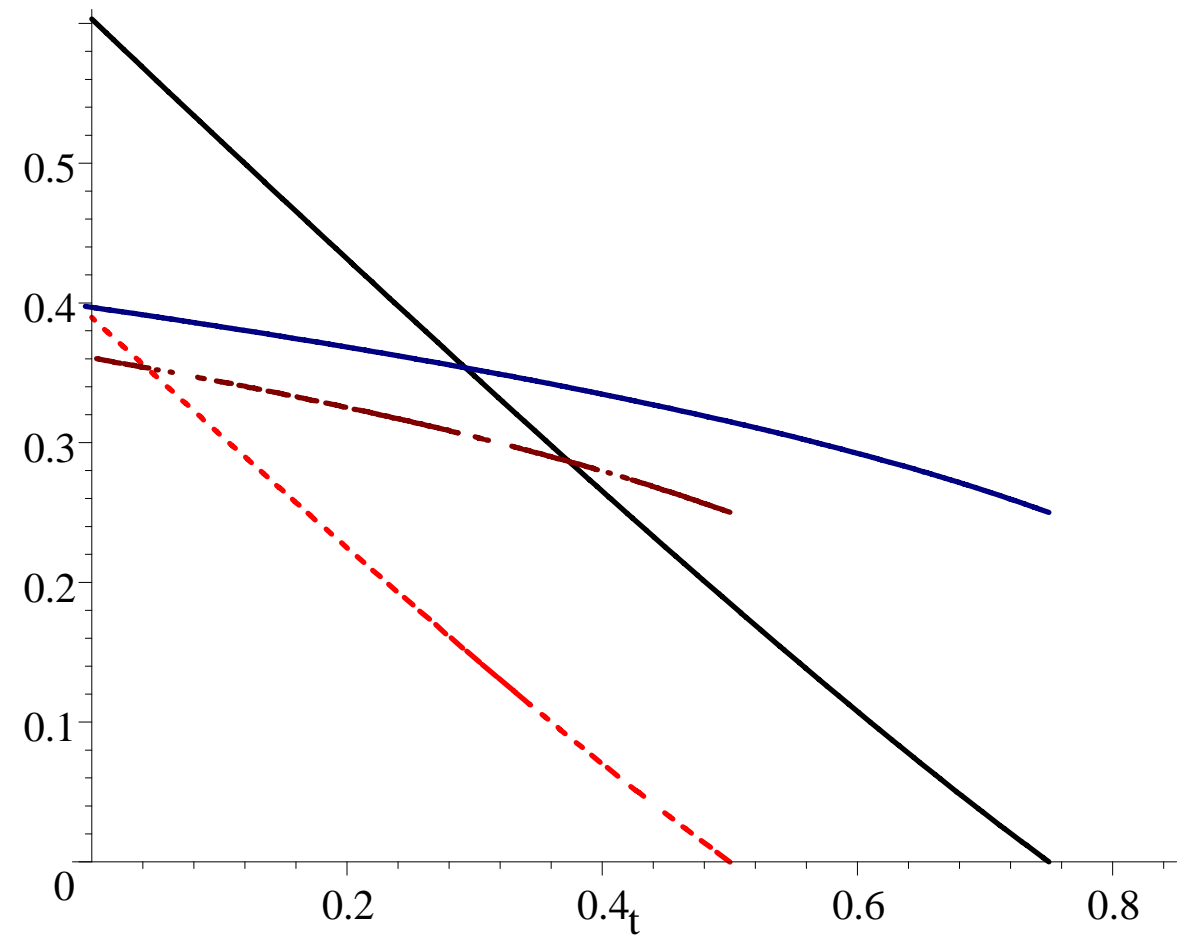

Figure 7: Equilibrium City and Suburban Rates of Slack as Functions of Transport Costs

Legend: Solid line show $p_{A}=1 / 4 ;$ dashed lines show $p_{A}=1 / 3$. Vertical axis shows rates of slack, horizontal scale shows transport costs. Curvier lines represent city rates of slack.

\subsection{City Population in Equilibrium}

In Nash equilibrium, the city's population is a function of agricultural rent and transport cost. Figure 8 shows the city population as a function of transportation costs with the agricultural rent held fixed at $1 / 4$ and $1 / 3$. As expected, the city's population increases as transportation costs rise, because this increases the 
city's locational advantage. The city population also increases as the value of agricultural land increases.

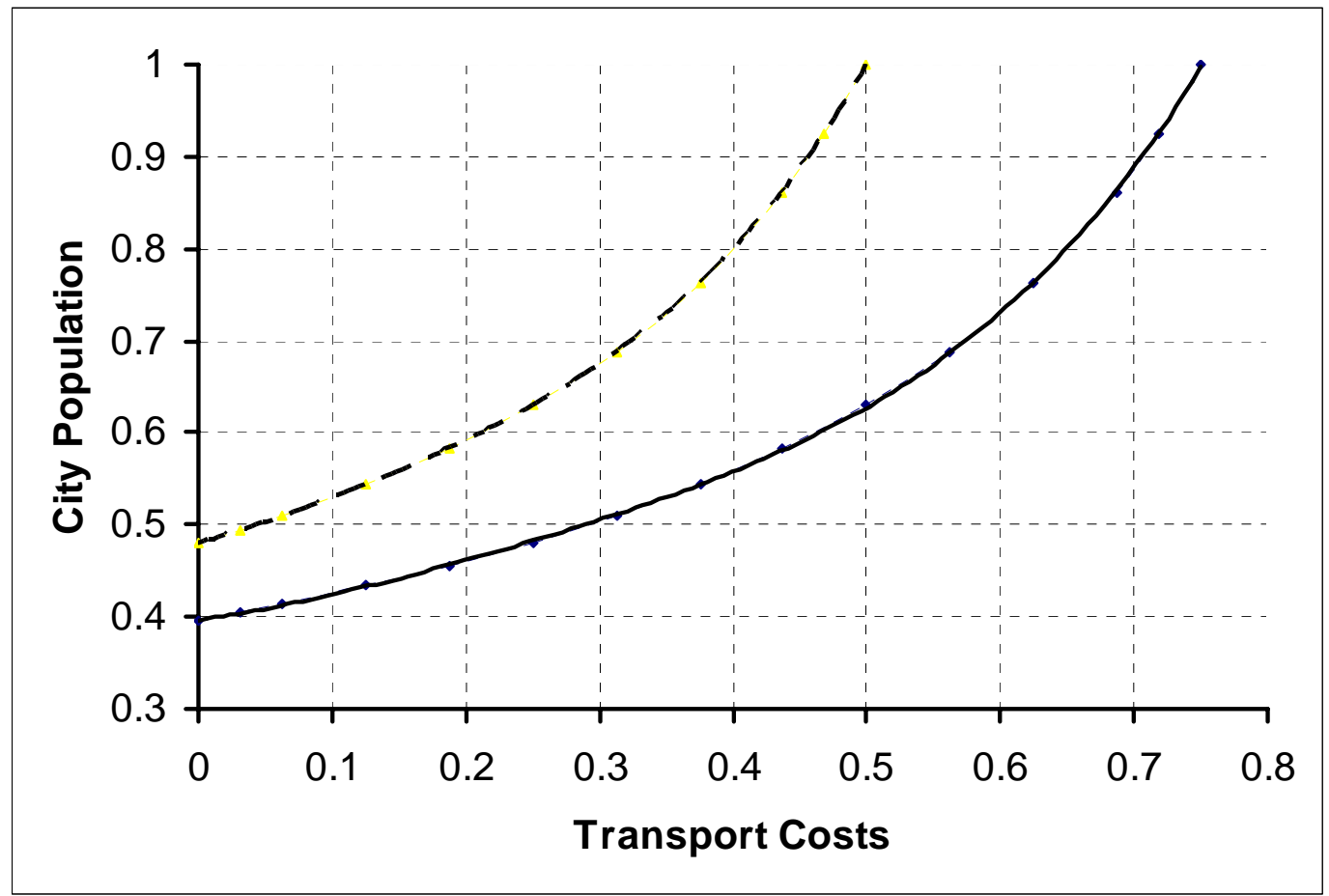

Figure 8: Equilibrium City Population as a Function of Transport Costs

Legend: Solid line shows $p_{A}=1 / 4 ;$ dashed line shows $p_{A}=1 / 3$.

Reducing transportation costs makes the suburbs more attractive, but the city retains a large proportion of the metropolitan population even when transport costs vanish. Because city and suburban rates of slack rise to offset decreased transportation costs, total slack is at its maximum when transport costs are zero. Figure 9 shows the combined total slack $\left(N_{C} \gamma_{C}+N_{S} \gamma_{S}\right)$ and the sum of total transport costs and combined total slack $\left(N_{C} \gamma_{C}+N_{S}\left(t+\gamma_{S}\right)\right)$ as a function of transportation costs for two values of agricultural land. These functions coincide where transport costs are zero and where the suburban population is zero. Higher 
agricultural land values reduce levels of slack. Higher transportation costs reduce total slack but at a decreasing rate, while the sum of total transport costs and total slack decreases at an increasing rate.

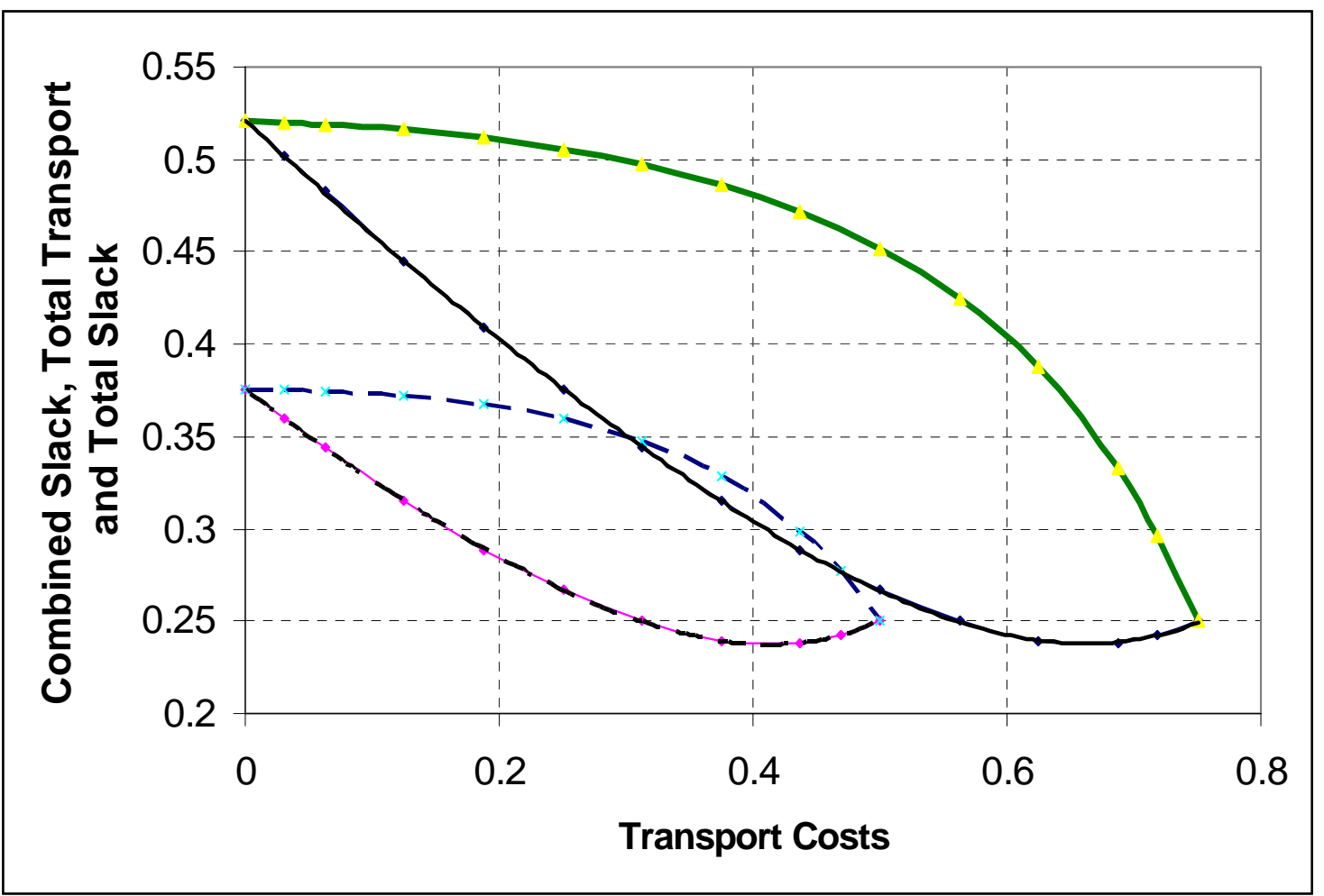

Figure 9: Combined Total Slack as a Function of Transport Costs

Legend: Lower branches show combined total slack. Upper branches show total transport costs and combined total slack. Solid lines show combined total slack when $p_{A}=1 / 4$; dashed lines show when $p_{A}=1 / 3$.

Although total transport and total slack costs are minimized when transport costs are just high enough to drive the suburban population to zero, utility is maximized when transport costs are zero. This is shown in Figure 10. Higher agricultural land values shift utility downwards. The utility of landowners varies much less with transport costs: when $p_{A}=1 / 4$ utility ranges from a minimum 
of 4.17 when transport costs are zero to a maximum of 4.25 at the transport cost where the suburb disappears. The minimum utility for $p_{A}=1 / 3$ is 4.16 , implying that agricultural land prices have minimal effects on landowners' utility gradient with respect to transport costs.

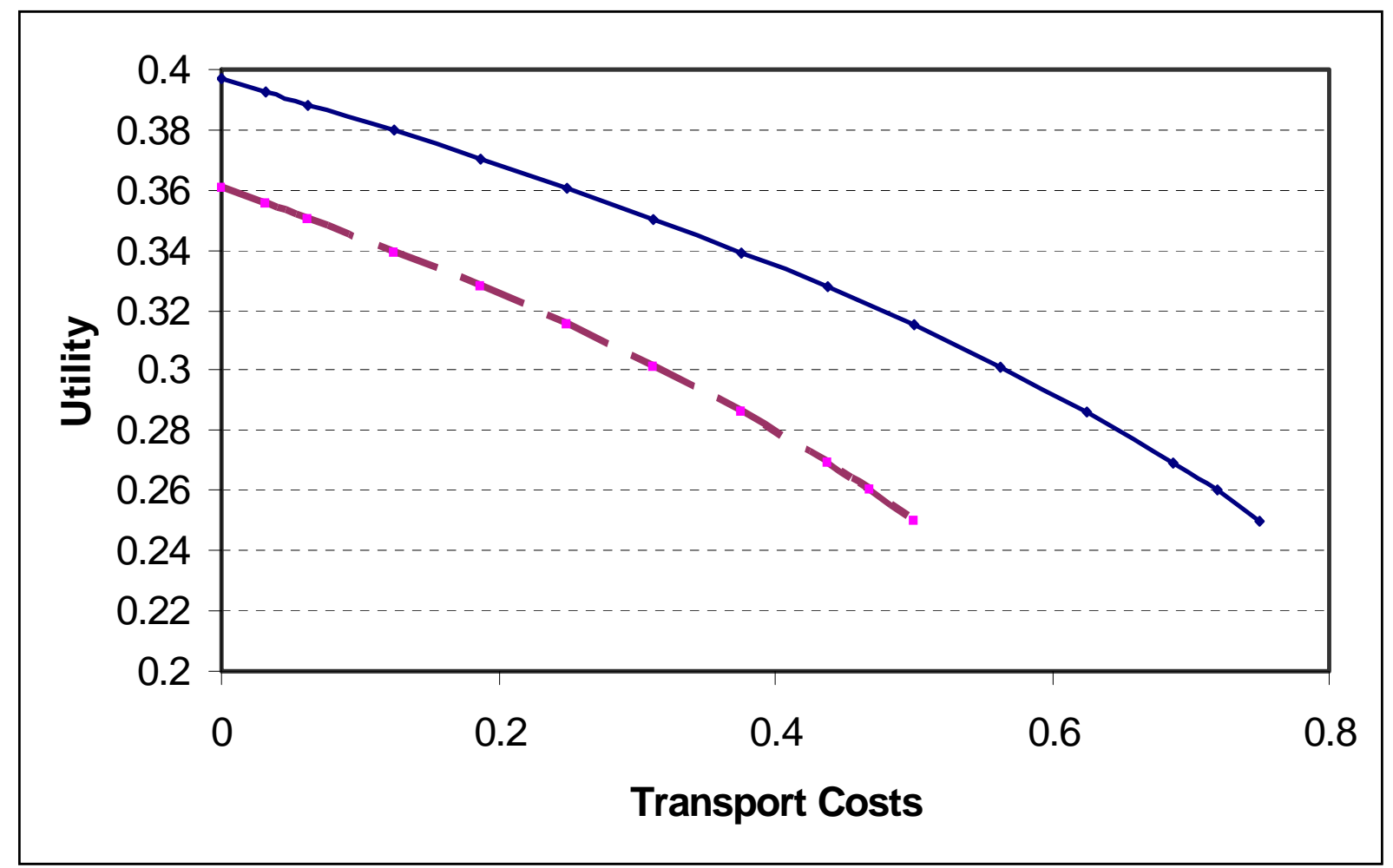

Figure 10: Maximum Utility for Non-Owners as a Function of Transport Costs

Legend: Solid line shows utility when $p_{A}=1 / 4$; dashed line shows when $p_{A}=1 / 3$. Endowment $\omega$ set to zero for these calculations.

\subsection{Capitalization Effects}

The city land market clearing condition $p_{C}^{*}=\frac{\sqrt{N_{C}}}{2}$ implies that the factors determining the city population will have similar effects on city housing prices. As higher rates of slack reduce the benefits city residents enjoy, rental rates for 
city land will decline according to the standard capitalization results for Alonzo location theory. The underlying economic parameters then affect city rental rates through the channels of slack and housing demand.

Figure 11 shows how city land prices depend on transport costs. The lower lines show the agricultural rental rate and the higher lines show the price of city housing. For example, the lower-lying solid line shows $p_{A}=1 / 4$ and the higherlying rental rate shows the corresponding city housing rate when $p_{A}=1 / 3$. With higher agricultural land prices the city land price function shifts downwards and becomes flatter.

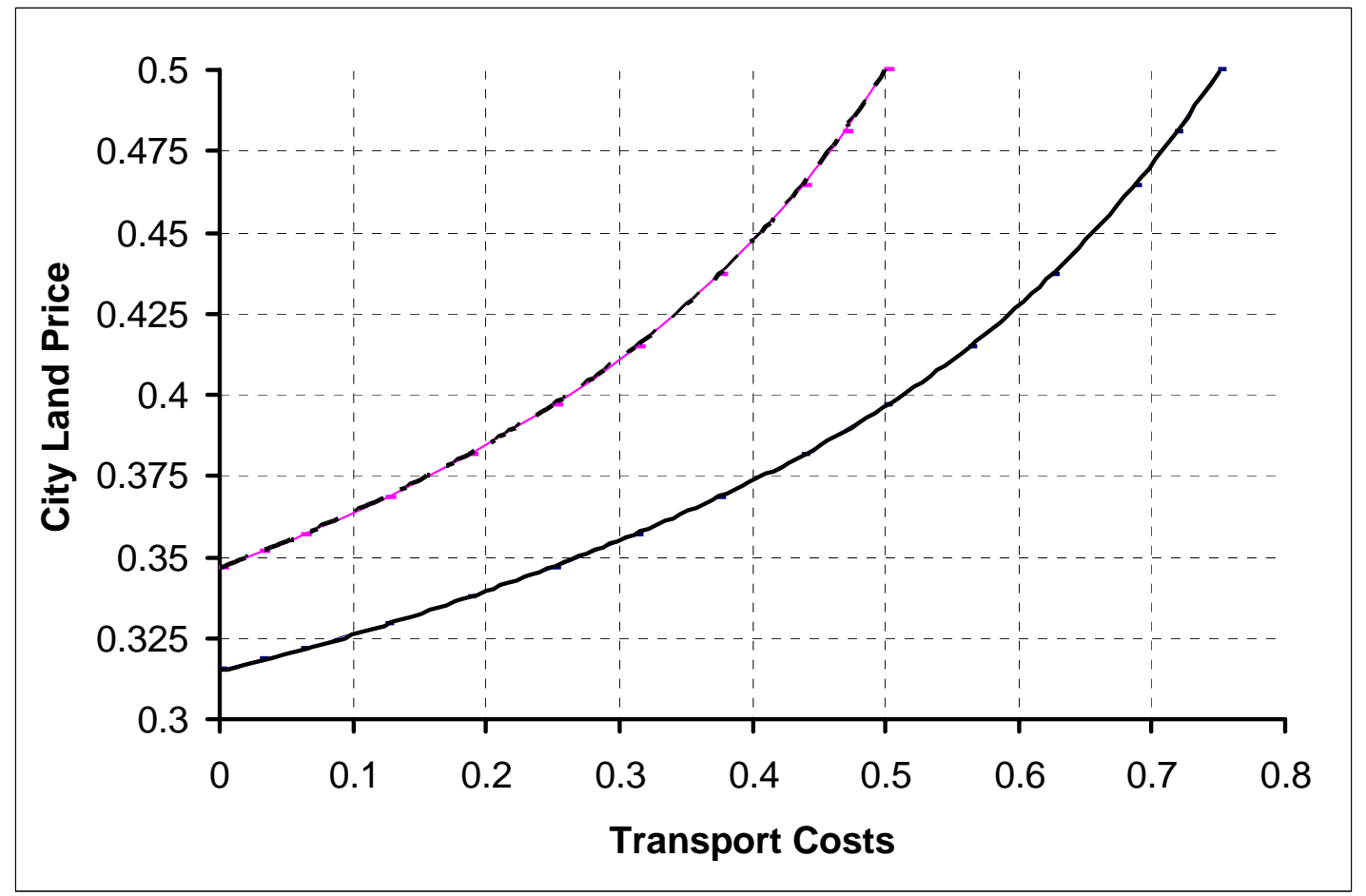

Figure 11: City Land Price in Equilibrium as a Function of Transport Costs

Legend: The solid line drawn for city rental rate when $p_{A}=1 / 4 ;$ dashed line when $p_{A}=1 / 3$. 


\section{Discussion and Conclusion}

While the Cournot model with two competing firms provides straightforward results, the analogous model for a competing city and suburb has both some familiar aspects and some surprises. Revenue maximization requires a unit elasticity rule and some comparative statics results resemble those drawn from nonstrategic spatial models. City housing prices rise with both transportation costs and the agricultural rental rate. However, this relationship is complicated by the strategic interaction of city and suburban politicians, which generates competition that allows residents to retain much of the land rents. This model, with suitable extensions to allow calibration with parameters drawn from empirical studies, could be used to estimate the benefits of governmental competition.

The model also highlights the fiscal interdependence of cities and their suburbs. Suburban competition acts to reduce slack and increase efficiency in the city's production of public goods valued by the median voter. On the other hand, cities with less efficient public production will give suburban politicians the opportunity to spend money on projects not highly valued by suburban voters, if those politicians are not restricted by political mechanisms.

This model can be used to analyze transportation cost by providing information about demand for better transport for each group in the metropolitan area. Lower transportation costs reduce the total amount of slack that city mayors can collect and increase the amount of slack the suburban mayors can collect. In this specification the suburban mayor's gains far exceed the city mayor's losses, so the combined total amount of slack grows as transport costs fall. Non-owners benefit from lower transportation costs while landowners are made slightly worse off so that a Benthamite welfare function increases as transport costs drop. The 
benefit principle then suggests that non-owners and suburban mayors should bear the burden of new transportation, although it is not obvious how to design tax instruments that would extract resources from suburban politicians. Conversely, landowners and city mayors will need to be compensated if they are able to block new transportation plans.

There are many ways to extend this simple model. Adding multiple suburbs would create a richer competitive environment, as suburban mayors would compete among themselves. Heterogeneity among suburbs would create an interaction between the rent gradient and strategic behavior. Heterogeneity among individuals would lead to sorting of residents by their characteristics, potentially allowing the city or suburbs to capture some differential rents. A convex housing supply function would change the strategic interaction between the city and its suburb by allowing the price of housing to differ from the price of raw land.

Finally, this model may provide insights for urban policy. Much of traditional urban policy assumes that consolidating jurisdictions would lead to lower costs of public provision and more equitable fiscal burdens. This tradition assumes consolidated jurisdictions can capture scale economies and geographically larger jurisdictions will be more effective in redistributive activities. However, consolidating governments also weakens the competitive pressures on public officials. Breton (1996) provides a detailed overview of these issues. The potential advantage of combining smaller jurisdictions into larger jurisdictions, or from not breaking up larger jurisdictions into more localized pieces will be at least partially offset by the effects of decreased governmental competition. Models that can present these tradeoffs in a clear and precise way bring important insights to debates about how to structure local governments in order to reduce taxes or provide better quality public services for their citizens. 


\section{References}

Brandl, John E. (1998). Money and Good Intentions are Not Enough. Brookings: Washington, D.C.

Breton, Albert (1996). Competitive Governments. Cambridge Univ. Press: Cambridge, UK.

Epple, Dennis and Allan Zelenitz (1981). "The Implications of Competition among Jurisdictions: Does Tiebout Need Politics?" Journal of Political Economy 89, 1197-1217.

Fujita, Masahisa (1989). Urban Economic Theory: Land Use and City Size. Cambridge Univ. Press : Cambridge, UK.

Konishi, Hideo (1996). "Voting with Ballots and Feet: Existence of Equilibrium in a Local Public Good Economy". Journal of Economic Theory 68, 480-509.

Persson, Torsten, Gerard Roland and Guido Tabellini (2000). "Comparative Politics and Public Finance." Journal of Political Economy 108, 1121-1161.

Singh, Nirvankar and Xavier Vives (1984). "Price and Quantity Competition in a Differentiated Duopoly." Rand Journal of Economics 15, 546-554.

Wildasin, David E. (1988). "Nash Equilibrium in Models of Fiscal Competition." Journal of Public Economics 35, 229-240.

Wildasin, David E. (2003). "Fiscal Competition in Space and Time." Journal of Public Economics 87, 2571-2588.

Vives, Xavier (1985). "On the Efficiency of Bertrand and Cournot equilibria with product differentiation." Journal of Economic Theory 36, 166-175. 


\section{Appendix: Derivations and Calculations}

\subsection{Corner Solutions: Omitted Calculations}

$$
\begin{aligned}
& s=\frac{\omega+p_{C} \cdot l l_{C}(i)-t-2 k p_{A} \sqrt{s}-\gamma_{S}}{p_{A}} \\
& s+2 k \sqrt{s}=\frac{\omega+p_{C} \cdot l /_{C}(i)-t-\gamma_{S}}{p_{A}} \text { Change variables to calculate: } x^{2}+2 k x= \\
& \frac{\omega+p_{C} \cdot l /_{C}(i)-t-\gamma_{S}}{p_{A}} \text { where } x=\sqrt{s}
\end{aligned}
$$

$$
\begin{aligned}
& x^{2}+2 k x-z=0, \text { Solution is: }\left\{x=-k+\sqrt{\left(k^{2}+z\right)}\right\},\left\{x=-k-\sqrt{\left(k^{2}+z\right)}\right\} \\
& s=-k+\sqrt{\left(k^{2}+\frac{\omega+p_{C} \cdot l / l_{C}(i)-t-\gamma_{S}}{p_{A}}\right)} \text { and } \tau_{S}^{*}=2 k p_{A} \sqrt{-k+\sqrt{\left(k^{2}+\frac{\omega+p_{C} \cdot l / l_{C}(i)-t-\gamma_{S}}{p_{A}}\right)}} .
\end{aligned}
$$

Only second solution is economically meaningful.

When owners are at a corner solution they will be the only suburban residents. After including the city housing market clearing condition their equal utility condition becomes:

$$
\begin{aligned}
& \sqrt{\frac{\omega+\sqrt{N_{C}}-t-\gamma_{S}}{p_{A}}}+k \ln \left(2 p_{A} \cdot \sqrt{-k+\sqrt{\left(k^{2}+\frac{\omega+\sqrt{N_{C}}-t-\gamma_{S}}{p_{A}}\right)}}\right) \\
= & \omega+\sqrt{N_{C}}+\frac{1}{2 \sqrt{N_{C}}}-k-\gamma_{C}+k \ln (1+\varepsilon) .
\end{aligned}
$$

No solution found. Cannot find solution in terms of city population.

\subsection{Proof of Proposition 1}

If the consumption constraint is strictly binding for non-owners and owners are decisive then

$$
s=\frac{\omega-t-k-\gamma_{S}}{p_{A}}<\frac{1}{4 p_{A}^{2}}
$$

So (i) $\frac{1}{2 p_{A}}>\sqrt{\frac{\omega-t-k-\gamma_{S}}{p_{A}}}$ and (ii) $\frac{1}{4 p_{A}}>\omega-t-k-\gamma_{S}$. The equal utility 
condition for owners is

$$
\frac{1}{4 p_{A}}=\frac{1}{2 \sqrt{N_{C}}}+\gamma_{S}-\gamma_{C}+t+k \ln (1+\varepsilon)
$$

A lemma is now needed to show that a key inequality holds.

Lemma: If the consumption constraint is strictly binding for nonowners then

$$
\frac{1}{4 p_{A}}>\sqrt{\frac{\omega-t-k-\gamma_{S}}{p_{A}}}-\left(\omega-t-k-\gamma_{S}\right) .
$$

Proof: Let $\omega-t-k-\gamma_{S}=W$ and $p_{A}=d>0$ and note $W \geq 0$. Then the inequality becomes:

$$
\begin{gathered}
\frac{1}{4 d}+W>\sqrt{\frac{W}{d}} \\
\left(\frac{1}{4 d}+W\right)^{2}=\frac{1}{16 d^{2}}+\frac{1}{2} \frac{W}{d}+W^{2}>\frac{W}{d} \\
W^{2}-\frac{1}{2} \frac{W}{d}+\frac{1}{16 d^{2}}=\left(W-\frac{1}{4 d}\right)^{2}>0
\end{gathered}
$$

which is true if $W \neq \frac{1}{4 d}$ or $\omega-t-k-\gamma_{S} \neq \frac{1}{4 p_{A}}$ but inequality (ii) implies this must hold.

Combining the inequality from the lemma and the owners' equal utility condition yields

$$
\sqrt{\frac{\omega-t-k-\gamma_{S}}{p_{A}}}<\omega+\frac{1}{2 \sqrt{N_{C}}}-k-\gamma_{C}+k \ln (1+\varepsilon) .
$$

This inequality states that non-owners get more utility from living in the city than they would living in the suburb. 


\subsection{Reaction Function Derivations}

\subsubsection{Population Supply Function for the City}

Derive population supply function from equal utility condition:

$$
\begin{aligned}
& \frac{1}{2 \sqrt{N_{C}}}+k \ln (1+\varepsilon)=\frac{1}{4 p_{A}}+\left(\gamma_{C}-\gamma_{S}\right)-t \text { equal utility condition } \\
& \frac{1}{\sqrt{N_{C}}}=2 \cdot\left[\frac{1}{4 p_{A}}+\left(\gamma_{C}-\gamma_{S}\right)-t-k \ln (1+\varepsilon)\right] \\
& N_{C}\left(p_{A}, \gamma_{C}, \gamma_{S}, t, k, \varepsilon\right)=\frac{1}{4 \cdot\left[\frac{1}{4 p_{A}}+\left(\gamma_{C}-\gamma_{S}\right)-t-k \ln (1+\varepsilon)\right]^{2}}=\frac{4 p_{A}^{2}}{\left[1+4 p_{A} \cdot\left[\left(\gamma_{C}-\gamma_{S}\right)-t-k \ln (1+\varepsilon)\right]\right]^{2}}= \\
\left(\frac{2 p_{A}}{1+4 p_{A} \cdot\left[\gamma_{C}-\gamma_{S}-t-k \ln (1+\varepsilon)\right]}\right)^{2} & N_{C}\left(p_{A}, \gamma_{C}, \gamma_{S}, t, k, \varepsilon\right)=\left(\frac{2 p_{A}}{1+4 p_{A} \cdot\left[\gamma_{C}-\gamma_{S}-t-k \ln (1+\varepsilon)\right]}\right)^{2} \\
& \text { check result: } \frac{1}{2 \sqrt{N_{C}}}=\frac{1}{4 p_{A}}+\left(\gamma_{C}-\gamma_{S}\right)-t-k \ln [(1+\varepsilon)], \\
& \text { Solution is: }\left\{N_{C}=4 \frac{p_{A}^{2}}{\left(1+4 \gamma_{C} p_{A}-4 \gamma_{S} p_{A}-4 t p_{A}-4 k(\ln (1+\varepsilon)) p_{A}\right)^{2}}=\left[\frac{2 p_{A}}{1+4 p_{A}\left(\gamma_{C}-\gamma_{S}-t-k(\ln (1+\varepsilon))\right)}\right]^{2}\right\}
\end{aligned}
$$

\subsubsection{Derivation of the City Mayor's Reaction Function}

$$
\frac{\partial N_{C}\left(\gamma_{S}, \gamma_{C}\right)}{\partial \gamma_{C}}=\frac{\partial\left[4 \left(\frac{p_{A}}{\left.\left.{ }^{4 p_{A}\left(-t+\gamma_{C}-\gamma_{2}\right)+1}\right)^{2}\right]}\right.\right.}{\partial \gamma_{C}}=32 \frac{p_{A}^{3}}{\left(4 p_{A} t-4 p_{A} \gamma_{C}+4 p_{A} \gamma_{2}-1\right)^{3}} \quad \text { derivative of }
$$

population w.r.t. city slack

$$
\begin{aligned}
& \frac{\partial N_{C}\left(\gamma_{S}, \gamma_{C}\right)}{\partial \gamma_{C}} \cdot \frac{\gamma_{1}}{N_{C}\left(\gamma, \gamma_{1}\right)}=32 \frac{p_{A}^{3}}{\left(4 p_{A} t-4 p_{A} \gamma_{C}+4 p_{A} \gamma_{2}-1\right)^{3}} \cdot \frac{\gamma_{1}}{\left[4\left(\frac{p_{A}}{1+4 p_{A}\left(-t+\gamma_{C}-\gamma_{S}\right)}\right)^{2}\right]}=\frac{8 \gamma_{1} p_{A}}{\frac{\left(4 p_{A} t-4 p_{A} \gamma_{C}+4 p_{A} \gamma_{2}-1\right)^{3}}{\left(1+4 p_{A}\left(-t+\gamma_{C}-\gamma_{S}\right)\right)^{2}}} \\
= & \frac{-8 p_{A} \gamma_{1}}{4 p_{A}\left(t-\gamma_{1}+\gamma_{2}\right)-1}
\end{aligned}
$$

set elasticity of population w.r.t. city slack equal to minus unity:

$$
\begin{aligned}
\frac{\partial N_{C}\left(\gamma_{C}, \gamma_{S}\right)}{\partial \gamma_{C}} \frac{\gamma_{C}}{N_{C}} & =\frac{8 p_{A} \cdot \gamma_{C}}{4 p_{A}\left(-t+\gamma_{C}-\gamma_{S}\right)+1}=-1 \\
8 \gamma_{C} p_{A} & =\left[4 p_{A}\left(-t+\gamma_{C}-\gamma_{S}\right)+1\right] \\
\gamma_{C}\left(\gamma_{S} ; t, p_{A}\right) & =\left(\frac{1}{4 p_{A}}-t-\gamma_{S}, 0\right)
\end{aligned}
$$

Note that the effect of a positive technology shock for the city has the same effect here as a decrease in transportation costs. 
Check result using partial of total revenue for city mayor:

$$
\begin{aligned}
& \frac{d}{d \gamma_{C}}\left[\gamma_{C}\left[\frac{1}{\frac{1}{2 p_{A}}+2\left[\left(\gamma_{C}-\gamma_{S}\right)-t-k \ln (1+\varepsilon)\right]}\right]^{2}\right]=\left[-4 p_{A}^{2} \frac{-1-2\left[2 \gamma_{C}-2 \gamma_{S}-2 t-2 k \ln (1+\varepsilon)\right] p_{A}+4 \gamma_{C} p_{A} 2}{\left(1+2\left[2 \gamma_{C}-2 \gamma_{S}-2 t-2 k \ln (1+\varepsilon)\right] p_{A}\right)^{3}}\right] \\
= & 0 \text {, Solution is: } \gamma_{C}=\frac{1}{4 p_{A}}-\left[\gamma_{S}+t+k \ln (1+\varepsilon)\right]
\end{aligned}
$$

\subsubsection{Suburban Mayor's Reaction Function}

$\frac{d}{d \gamma_{S}}\left[\gamma_{S} \cdot\left(1-\left[\frac{2 p_{A}}{1+4 p_{A}\left(\gamma_{C}-\gamma_{S}-t\right)}\right]^{2}\right)\right]=\frac{d}{d \gamma_{S}}\left[\gamma_{S} \cdot\left(1-\left[\frac{2 p_{A}}{1+4 p_{A}\left(\gamma_{C}-\gamma_{S}-t\right)}\right]^{2}\right)\right]$

illustrate various revenue parabolas

$$
\begin{aligned}
& {\left[\left[\left[\gamma_{S} \cdot\left(1-\left[\frac{2 p_{A}}{1+4 p_{A}\left(\gamma_{C}-\gamma_{S}-t\right)}\right]^{2}\right)\right]_{\gamma_{C}=1 / 4}\right]_{p_{A}=1 / 5}\right]_{t=1 / 2}=\gamma_{S}\left(1-\frac{4}{25\left(\frac{4}{5}-\frac{4}{5} \gamma_{S}\right)^{2}}\right)} \\
& {\left[\left[\left[\gamma_{S} \cdot\left(1-\left[\frac{2 p_{A}}{1+4 p_{A}\left(\gamma_{C}-\gamma_{S}-t\right)}\right]^{2}\right)\right]_{\gamma_{C}=1 / 4}\right]_{p_{A}=1 / 4}\right]_{t=1 / 3}=\gamma_{S}\left(1-\frac{1}{4\left(\frac{11}{12}-\gamma_{S}\right)^{2}}\right)} \\
& {\left[\left[\left[\gamma_{S} \cdot\left(1-\left[\frac{2 p_{A}}{1+4 p_{A}\left(\gamma_{C}-\gamma_{S}-t\right)}\right]^{2}\right)\right]_{\gamma_{C}=1 / 4}\right]_{p_{A}=1 / 5}\right]_{t=1 / 4}: \gamma_{S}\left(1-\frac{4}{25\left(1-\frac{4}{5} \gamma_{S}\right)^{2}}\right)} \\
& {\left[\left[\left[\gamma_{S} \cdot\left(1-\left[\frac{2 p_{A}}{1+4 p_{A}\left(\gamma_{C}-\gamma_{S}-t\right)}\right]^{2}\right)\right]_{\gamma_{C}=1 / 4}\right]_{p_{A}=1 / 5}\right]_{t=1 / 5}: \gamma_{S}\left(1-\frac{4}{25\left(\frac{26}{25}-\frac{4}{5} \gamma_{S}\right)^{2}}\right)} \\
& {\left[\left[\left[\gamma_{S} \cdot\left(1-\left[\frac{2 p_{A}}{1+4 p_{A}\left(\gamma_{C}-\gamma_{S}-t\right)}\right]^{2}\right)\right]_{\gamma_{C}=1 / 4}\right]_{p_{A}=1 / 3}\right]_{t=1 / 4}=\gamma_{S}\left(1-\frac{4}{9\left(1-\frac{4}{3} \gamma_{S}\right)^{2}}\right)} \\
& \left.\left[\left[\left(1-\left[\frac{2 p_{A}}{1+4 p_{A}\left(\gamma_{C}-\gamma_{S}-t\right)}\right]^{2}\right)\right]_{\gamma_{C}=1 / 4}\right]_{t=.25}\right]_{p_{A}=1 / 5}=1-\frac{4}{25\left(1-\frac{4}{5} \gamma_{S}\right)^{2}}
\end{aligned}
$$

suburban population: bowed-out line is suburban population for $\gamma_{C}=1 / 4$, $t=.25, p_{A}=1 / 5$.

Check that suburban reaction function actually picks maximum of revenue hill: (for lowest shown revenue hill)

$$
\begin{aligned}
& {\left[\left[\left[\frac{Q\left(\gamma_{C}, p_{A}, z\right)}{12 p_{A}}-\frac{p_{A}}{Q\left(\gamma_{C}, p_{A}, z\right)}+\frac{1}{4 p_{A}}+\left(\gamma_{C}-t\right)\right]_{\gamma_{C}=1 / 4}\right]_{p_{A}=1 / 3}\right]_{t=1 / 4}=} \\
& \frac{1}{36} \sqrt[3]{(36 \sqrt{247} \sqrt{243}-8748)}-\frac{3}{\sqrt[3]{(36 \sqrt{247} \sqrt{243}-8748)}}+\frac{3}{4}=0.14329
\end{aligned}
$$




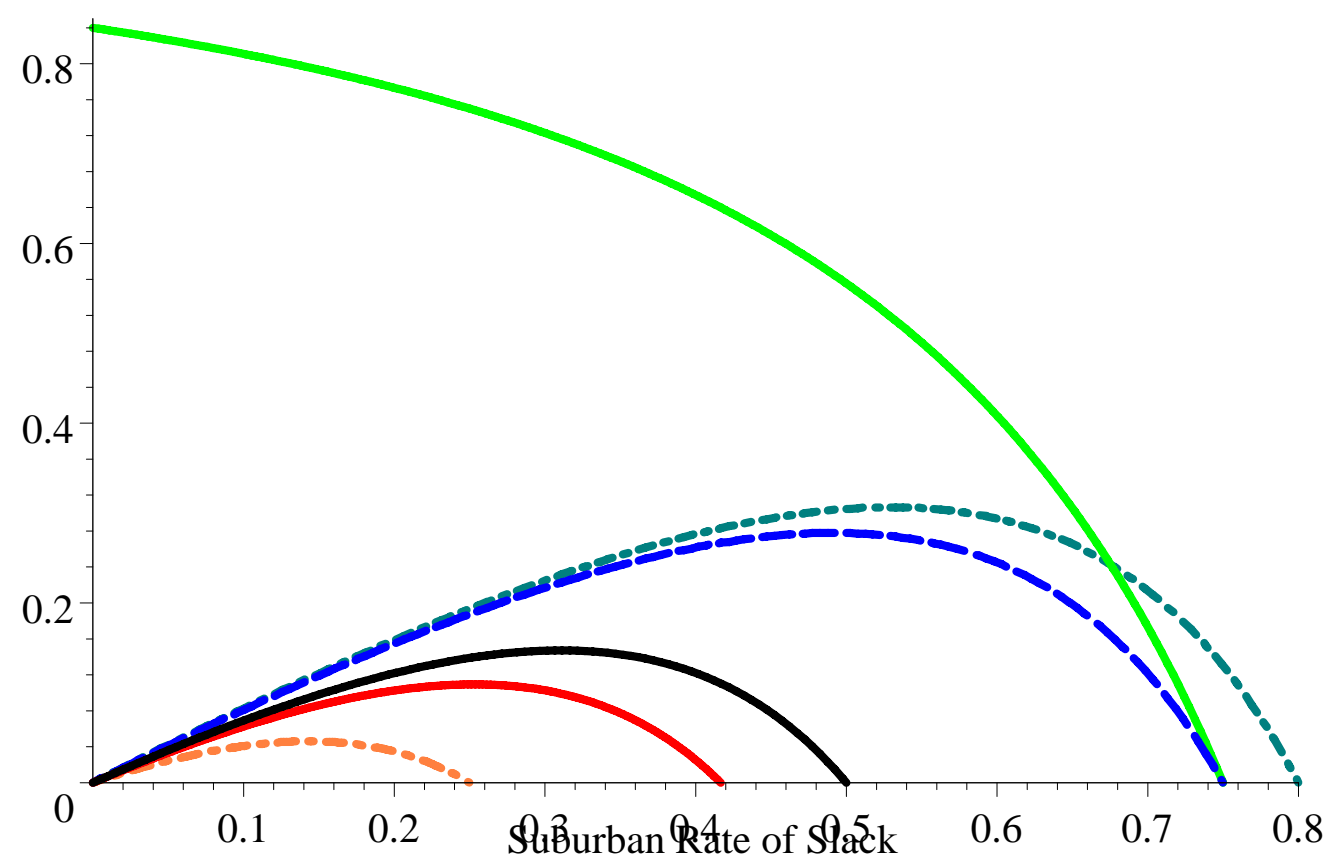

Suburban Population and Total Slack

\subsection{Nash Equilibria}

Find analytic expression for Nash equilibrium values:

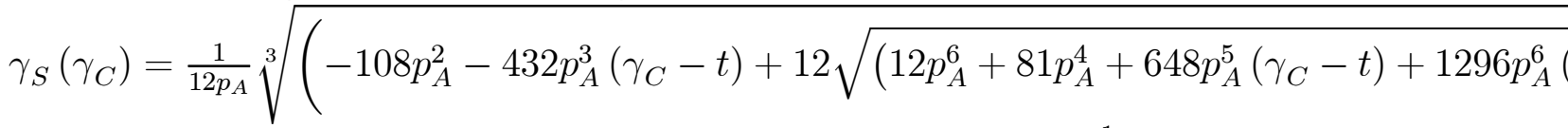

$$
\begin{aligned}
& -\frac{p_{A}}{\sqrt[3]{\left(-108 p_{A}^{2}-432 p_{A}^{3}\left(\gamma_{C}-t\right)+12 \sqrt{\left(12 p_{A}^{6}+81 p_{A}^{4}+648 p_{A}^{5}\left(\gamma_{C}-t\right)+1296 p_{A}^{6}\left(\gamma_{C}-t\right)^{2}\right)}\right)}}+\frac{1}{4 p_{A}}+\left(\gamma_{C}-t\right) \\
& \gamma_{C}\left(\gamma_{S} ; t, p_{A}\right)=\left(\frac{1}{4 p_{A}}-t-\gamma_{S}, 0\right)
\end{aligned}
$$

invert city mayor's reaction function $\left\{\gamma_{S}=\frac{1}{4 p_{A}}-t-\gamma_{C}\right\}$ to get $\gamma_{C}-t=$ $\left(\frac{1}{4 p_{A}}-2 t-\gamma_{S}\right)$

Solve for city mayor's Nash equilibrium value:

$$
\begin{aligned}
& \frac{1}{4 p_{A}}-t-\gamma_{C}= \\
& \frac{1}{12 p_{A}} \sqrt[3]{\left(-108 p_{A}^{2}-432 p_{A}^{3}\left(\gamma_{C}-t\right)+12 \sqrt{\left(12 p_{A}^{6}+81 p_{A}^{4}+648 p_{A}^{5}\left(\gamma_{C}-t\right)+1296 p_{A}^{6}\left(\gamma_{C}-t\right)^{2}\right)}\right)}
\end{aligned}
$$


$-\frac{p_{A}}{\sqrt[3]{\left(-108 p_{A}^{2}-432 p_{A}^{3}\left(\gamma_{C}-t\right)+12 \sqrt{\left(12 p_{A}^{6}+81 p_{A}^{4}+648 p_{A}^{5}\left(\gamma_{C}-t\right)+1296 p_{A}^{6}\left(\gamma_{C}-t\right)^{2}\right)}\right)}}+\frac{1}{4 p_{A}}+\left(\gamma_{C}-t\right)$,

Solution not found: Closed form solutions are not possible. 
Individual researchers, as well as the on-line and printed version of the CERGE-EI Working Papers Series (including their dissemination) were supported from the following institutional grants:

- Economic Aspects of EU and EMU Entry [Ekonomické aspekty vstupu do Evropské unie a Evropské měnové unie], No. AVOZ70850503, (2005-2010);

- Economic Impact of European Integration on the Czech Republic [Ekonomické dopady evropské integrace na ČR], No. MSM0021620846, (2005-2011);

Specific research support and/or other grants the researchers/publications benefited from are acknowledged at the beginning of the Paper.

(c) D. Andrew Austin, 2005

All rights reserved. No part of this publication may be reproduced, stored in a retrieval system or transmitted in any form or by any means, electronic, mechanical or photocopying, recording, or otherwise without the prior permission of the publisher.

Published by

Charles University in Prague, Center for Economic Research and Graduate Education (CERGE) and

Economics Institute (EI), Academy of Sciences of the Czech Republic

CERGE-El, Politických vězñu 7, 11121 Prague 1, tel.: +420 224005 153, Czech Republic.

Printed by CERGE-EI, Prague

Subscription: CERGE-El homepage: http://www.cerge-ei.cz

Editors: Directors of CERGE and EI

Managing editors: Deputy Directors for Research of CERGE and EI

ISSN 1211-3298

ISBN 80-7343-044-4 (Univerzita Karlova v Praze, CERGE)

ISBN 80-7344-033-4 (Národohospodářský ústav AV ČR, Praha) 
CERGE-EI

P.O.BOX 882

Politických vězňů 7

11121 Praha 1

Czech Republic http://www.cerge-ei.cz 